\title{
Discovering the Role of Emotional and Rational Appeals and Hidden Heterogeneity of Consumers in Advertising Copies for Sustainable Marketing
}

\author{
Cheong Kim ${ }^{1,2}$, Hyeon Gyu Jeon ${ }^{1}$ and Kun Chang Lee ${ }^{1,3, * \mathbb{C}}$ \\ 1 SKK Business School, Sungkyunkwan University, Seoul 03063, Korea; saga@g.skku.edu (C.K.); \\ hyeongyu.jeon@gmail.com (H.G.J.) \\ 2 Predictive Analytics and Data Science, Economics Department, Airports Council International (ACI) World, \\ Montreal, QC H4Z 1G8, Canada \\ 3 Samsung Advanced Institute for Health Sciences \& Technology (SAIHST), Sungkyunkwan University, \\ Seoul 03063, Korea \\ * Correspondence: kunchanglee@gmail.com
}

Received: 13 May 2020; Accepted: 24 June 2020; Published: 25 June 2020

\begin{abstract}
Advertising copies have been considered as a fundamental strategy for firms to continue sustainable marketing strategies. In order to provide the advancement of previous research and practical implication to marketers in the field for sustainable marketing strategy, this research tried to reveal the role of emotional and rational appeals as well as hidden heterogeneity of consumers in the appeal-value-trust-satisfaction-WOM framework. By applying the PLS-SEM and PLS-POS approach to 230 valid questionnaire samples, we could discover the role of appeals in the framework as well as three types of unobserved heterogeneity among the respondents. Both emotional and rational appeals had significant influences on the value-satisfaction-trust-WOM context. In addition, for hidden consumer traits in advertising copies, we revealed three types of consumer groups: Type 1 , the consumer group with a rational orientation $(n=68)$; Type 2 , the group with an emotional orientation $(n=74)$ and Type 3 , the group with a utilitarian orientation. This research provided contributions by offering some insight into ways to establish sustainable marketing strategies in advertisements and to address unobserved heterogeneity consumers in advertising copy appeals.
\end{abstract}

Keywords: advertising copy; smartphone consumer; consumer typology; sustainable marketing; unobserved heterogeneity

\section{Introduction}

When ancient Egyptians were creating advertisements of gold reward for fugitive slaves on papyrus [1], they would not have reckoned that their descendants, after three thousand years later, are using similar techniques for other purposes. Because advertising is the act of an explicit advertiser unilaterally communicating through the media to change the recipient's attitude toward the advertisement, advertisements are broadly used for purposes in both public and private interests [2-6]. Advertising has been considered one of the most effective and influential activities for corporates to maximize its sales today [7-10]. Building adequate advertising strategies would be one of the fundamental movements of corporations as a sustainable marketing tactic.

The visualization of advertisements has become very imperative due to the influence of various forms of online advertising following the rapid development of the Internet and telecommunications technology as well as television and printed material. However, advertising copies are still inevitable to appeal to the unique selling points of specific products or services implicitly. We could argue that advertising copies are a fundamental element of the marketing mix that may significantly impact on 
the success of products or services, which would directly influence the sustainable marketing activities of firms.

According to Fuller [11], sustainable marketing could be identified as the procedure of scheduling, adopting and managing in the several aspects of products and services, including pricing, promotion and distribution, in a manner that meets the following three requirements: fulfillment of consumer needs, attainment of firms' goal and securing the process competitiveness in the ecosystem. From the perspective of sustainable marketing, advertising copy could also be one of the critical components for achieving these above requirements because it should reflect the abilities products and services that would satisfy consumers' needs, it should be able to meet the goal of the firm by successfully inducing consumers to purchase products or services, and it should express that products or services are superior to competitors' in the market as well. The overarching philosophy of launching advertising copies in the media channels would not be meaningful at all otherwise.

Meanwhile, worldwide smartphone sales are expected to grow $3 \%$ to reach nearly 1.57 billion units in 2020 [12]. This steady popularity has made smartphones as one of the essential items in modern daily lives. Consumers are exposed universally to countless advertisements on their smartphone devices, and these are delivered through such small devices as smartphones that have more abundant modes of presentation, including text, icons, graphic features, pictures and even video clips [13]. Most types of advertisements for information about products and services that are delivered in smartphone devices contain only a few words due to the limitation of display size. However, these advertisements made of a few words lack graphics, dynamic processes and an attractive design, which limits the effective delivery of denotations [14]. To convey advertising copies' information and connotation that were intended by products and services providers to consumers effectually, it is necessary to understand not only what attracts consumers' attention, but also what are the differences in consumers' hidden traits.

The effectiveness of advertising transmitted to consumers varies depending on their thoughts and feelings, and this idea suggests that both emotional and rational appeals contribute to the efficiency of advertisements [15]. Understanding of behavioral and psychological reactions of consumers to those appeals from advertising copies is a fundamental basis of sustainable marketing because it would not derive adequate results without it just like the failure case with marketing myopia of Woolworth's mousetrap [16]. In previous literature in the field of marketing, it was believed that advertising should be rational and measurable [17-19]. However, researchers also have argued that emotion acts as a significant antecedent that affects consumers' responses, such as attitudes toward the advertisement, brand, purchase intention and positive word of mouth [20-23]. Rational (cognitive) advertising messages provide information to persuade through logical appeals to recipients. Alternatively, emotional (affective) ad messages attempt to influence through psychological urges. However, the effects of emotional and rational appeals would be inconsistent in determining advertising effectiveness [15]. In other words, if firms only emphasize a specific aspect of advertising, such as emotional or rational impact, they may face big failure in their marketing activities that could severely harm sustainable marketing strategies. From the perspective of sustainable marketing, it is necessary to tackle both emotional and rational messages in advertising copies to more effectively induce consumers to make positive decisions on purchasing products and services.

However, would it be sufficient just to discover the roles of emotional and rational appeals toward consumers in advertising copies? Unlikely the past, consumers nowadays are exposed to various sources of information due to the dramatic evolution of ICT that help consumers make appropriate decisions for purchasing products and services $[24,25]$. Consumers could easily digest information that firms produce and release online according to the analysis of consumers' needs and make decisions about purchasing products and services based on their acquisition. However, information about the products and services offered by firms may likely be produced based on consumer preferences that are generally readily apparent. In other words, the hidden heterogeneity of consumers may have a substantial impact on their decision-making. 
In order to advance the previous research as well as provide the sustainable marketing strategy to the practitioners in the field, this study emphasized the additional concepts of emotional and rational appeals as well as trust in advertising copies that were applied to unobserved heterogeneity in the research framework of the value, satisfaction and WOM in the context of smartphone markets. Smartphone advertisements are highly suitable for observations of advertising's emotional and rational appeals' effects because smartphones are convergent media that influence making both rational and emotional decisions, and they appeal both to users' task- and affect-oriented needs and motivations [26]. In addition, identifying consumer typology by exploring unobserved heterogeneity in consumer groups could help establish an evolving sustainable marketing strategy using advertising copies. The purpose of this study was to reveal the role of emotional and rational appeals of smartphone advertising copies that consumers could see on their mobile phone devices and the unobserved heterogeneous consumer traits in the research framework of appeal-value-satisfaction-trust-positive WOM from the perspectives of smartphone consumers. This research has a contribution in the advancement of prior research with value, satisfaction and WOM (word-of-mouth) framework by adding additional constructs, such as emotional and rational advertising copy appeals and affective and cognitive trust, and the revealing hidden heterogeneous traits of consumers from the perspective of the smartphone market, which were rarely tried in other research, as well as providing practical applications for helping marketing practitioners in the filed establish sustainable marketing strategies.

The remainder of this research is ordered as follows. The next part scrutinizes the relevant previous literature and establishes the hypotheses for this study. The third part suggests the methodological approach with the data sample, and the next part provides the test results. Finally, the last section includes implications, limitations and future study suggestions.

\section{Theoretical Background and Hypotheses}

\subsection{Appeals and Value in Advertising Copies}

Advertising appeals reflect a product's attributes, benefits and even its brand image that corporations would like to express within them. These appeals can be classified into such discrete categories as rational and emotional [27]. Emotional appeals represent a psychological, social or symbolic desire that motivates consumers to purchase the product because of the feelings it elicits [28-30]. On the other hand, rational (informational) appeals refer to the consumer's logical beliefs and attitudes about the product's benefit or function [28-30].

Meanwhile, value motivates people to engage in a specific behavior [31]. It is the most general concept that represents consumer's behavior based on acquisition, transaction, in-use or redemption [32]. First of all, value was conceptualized as a tradeoff between quality and price [33,34]. In many studies, consumers' perceived value has been studied universally according to two dimensions, utilitarian value hedonic value $[35,36]$. Hedonic value refers to consumers' evaluation of experiential benefits and costs overall, such as adventure, social, gratification, idea and role [36-38].

Adaval [39] argued that consumers' affective confirmation in the information of advertisement that would be derived from the emotional appeal of advertising copies were more significantly related to hedonic criteria than utilitarian criteria. In addition, Geuens et al. [40] discovered that emotional advertising was effective for hedonic products and low involvement using TV commercials. With respect to consumer attitudes toward advertising, emotional advertising stimulates their perception of hedonic value and we propose the following hypothesis:

Hypothesis 1 (H1). Emotional ad appeal will positively influence hedonic value.

On the other hand, utilitarian value refers to consumers' assessment of the functional benefits and costs overall associated with achieving their specific purpose, such as product offerings, product information, convenience, monetary savings [36,37,41-44]. Johar and Sirgy [45] suggested that functional congruity that could be derivative from rational advertising copies had a strong 
relationship with those utilitarian products. Emotional advertising could have a more significant effect on hedonic products, while rational advertising's effectiveness could be significant in utilitarian products [39,45]. Geuens et al. [40] used TV commercials to reveal that non-emotional advertising had an influence on utilitarian products and high involvement using. With respect to consumer attitudes toward advertising, rational advertising appeals encourage consumers' perceptions of utilitarian value. Based on the discussion, we proposed the following hypotheses:

Hypothesis 2 (H2). Rational ad appeal will positively influence utilitarian value.

\subsection{Value, Trust and Satisfaction in Advertising Copies}

Value and trust have similar effects with respect to the relation between satisfaction and loyalty [46]. Trust is a psychological state that comprises the intention to accept vulnerability based upon positive expectations of others' intentions or behaviors [47]. In addition, trust in advertising could be defined as confidence that advertising is a reliable source of product and service information and a willingness to act based on that information [48]. Although trust has been regarded as an essential antecedent of value in the literature, authors also have proposed a significant converse relation that assumes that perceived value is a prerequisite for trust [32,35]. Chai et al. [49] used the two-dimensional model to discover the interrelationship of trust and value and revealed that building cognitive trust strong impact on delivering utilitarian value to increase consumers' repeat purchase intention while affective trust had a significant influence on hedonic value delivery.

When conceptualized as having multidimensional components (affective vs. cognitive), hedonic elements that were derived by emotional appeal could impact on the affective trust. This concept was based on the way one feels about such trust attributes as warmth and openness while interacting with the object. In comparison, knowledge, such as utilitarian elements, inspires cognitive trust and is based on a rational approach to evaluating an object's reliability, credibility and related trust attributes based on specific examples [50]. Value also is a crucial determinant of preference, satisfaction, loyalty and other vital outcomes [51]. Based on the discussion in value, trust and satisfaction, we propose the following hypothesis:

Hypothesis 3 (H3). Hedonic value will positively influence affective trust (H3a) and satisfaction (H3b).

Hypothesis 4 (H4). Utilitarian value will positively influence cognitive trust (H4a) and satisfaction (H4b).

In addition to trust, satisfaction in advertising copied could be considered as the degree to which consumers' assessment of the product information advertising copy provides reflects their needs and expectations [52]. Satisfaction has been recognized as one of the fundamental causes of trust [53-56]. In advertising, satisfaction for advertising copies about brands, products, and services could be either major antecedents or descendants [57,58]. These arguments imply that the relationship between satisfaction and trust of consumers could be remarkably imperative, and the impression from the satisfaction that impacts trust in advertising copies would be substantial for firms to carry on sustainable marketing. Based on the theoretical background in satisfaction, we propose the following hypothesis:

Hypothesis 5 (H5). Satisfaction will positively influence affective trust (H5a) and cognitive trust (H5b).

\subsection{Positive Word-of-Mouth}

Positive WOM is regarded as a sustainable marketing tool that could strongly influence consumers' loyalty to the brand and the intention of purchase [59-62]. Positive WOM also refers to a consumer's positive statement about a product in advertising [63]. In this regard, we presumed that positive WOM needs to be pointed out in this study of discovering appropriate strategies in advertising copies based on consumer traits for sustainable marketing. Furthermore, consumers' attention to advertisements [48] 
and advertising appeals $[64,65]$ are related significantly to their trust of advertising, which implies that trust affects their loyalty, such as WOM recommendations [66,67]. Researchers argued that satisfaction was strongly related to WOM; for example, enhancement of consumer satisfaction could be a key driver to bring positive WOM [68-70]. Maxham III [71] argued that positive WOM was significantly influenced by consumers' satisfaction in the context of high-level service recovery. Ranaweera and Prabhu [72] also suggested that satisfaction was the determinant of customer retention and positive WOM. Accordingly, based on the discussion above, we propose the following hypothesis:

Hypothesis 6 (H6). Satisfaction will positively influence positive WOM.

As a driver that induce consumers' to have positive WOM toward products and services, Ranaweera and Prabhu [72] proposed consumers' trust in firms. Agag and El-Masry [73] proved that consumer intention to purchase travel online and making positive WOM was effected by trust, based on an integrated analysis of innovation diffusion theory and TAM with trust. To be more specific about affective trust, Wang and Chen [74] suggested that affective trust was one of the most crucial determinants of consumers' behavior of positive WOM with interactional justice dominates. Xu [75] also discovered affective trust that could be found in the reviewers' profile strongly influenced eWOM credibility. Meanwhile, Alfina et al. [76] argued that consumers' cognitive trust in C2C e-commerce sites had a significant impact on e-WOM that would bring higher purchase intention. $\mathrm{Xu} \mathrm{[75]} \mathrm{also}$ revealed that cognitive trust in the reviewers' profile had an impact on eWOM credibility along with affective trust. Based on the theoretical background in trust and positive WOM, we suggest the following hypotheses:

Hypothesis 7 (H7). Affective trust will positively influence positive WOM.

Hypothesis 8 (H8). Cognitive trust will positively influence positive WOM.

\subsection{Consumers' Hidden Heterogeneity}

In empirical studies of social and behavioral sciences, such as marketing, erroneous data homogeneity cause long have been pointed out as problems [77,78]. Heterogeneity studies have been conducted steadily but have been confined mainly to the observed features and focused on variables' moderating effects, a priori groupings and contextual factors in the research models. Emphasizing that unobserved heterogeneity threatens empirical results and interpretations, researchers in several fields have underscored the need for studies of such heterogeneity [77,79-82]. For example, researchers may make errors that ignore the significant differences in heterogeneous subgroups by overgeneralizing the results of the sample overall (Type I error). Further, they also may make errors that accept nonsignificant effects from the sample overall that occur because of significant reversal effects in the subgroups (Type II error). Researchers will draw invalid conclusions by ignoring the considerable heterogeneity in the unobserved groups that can bias the parameter estimates that result in Type I and II errors [77]. Other previous research argued that unobserved heterogeneity influences WOM (word-of-mouth) [83-86]. Notably, Fuentes-Blasco, Moliner-Velázquez and Gil-Saura [83] articulated that unobserved heterogeneity had a substantial impact on the framework of value, satisfaction and WOM (word-of-mouth) relationship [83]. We proposed the last hypothesis:

Hypothesis 9 (H9). There exists unobserved heterogeneity in the model that underlies the advertising appeal, perceived value, satisfaction and trust of individuals that influence positive WOM from the perspective of smartphone consumers. 


\subsection{Research Model}

The following conceptual research was formed based on the hypotheses that we derivative from the literature review. From the perspective of a sustainable marketing strategy establishment for practitioners in the field of smartphone markets, we suggest the research model of this study, as illustrated in Figure 1.

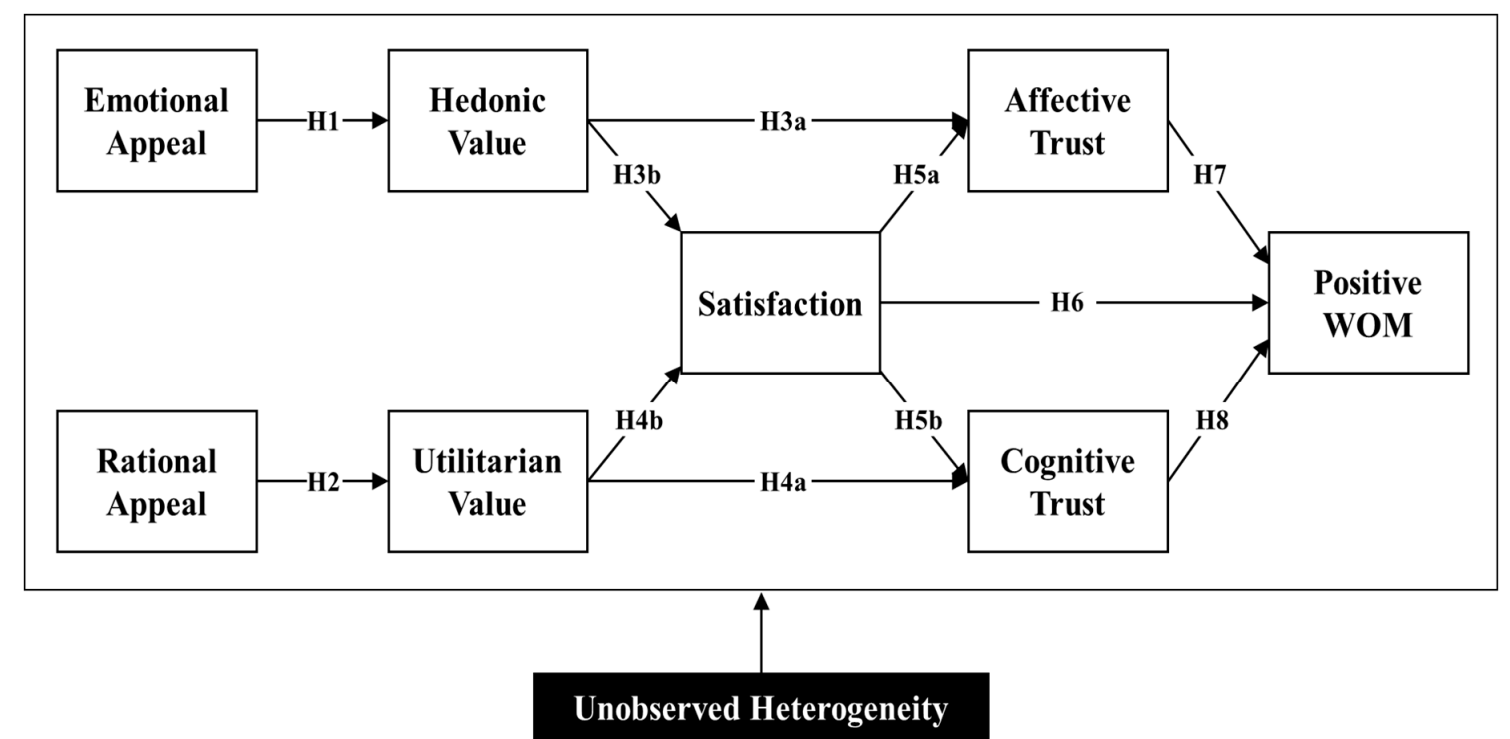

Figure 1. Research model.

\section{Methods}

\subsection{Participants}

We recruited college students as participants in our experiments. A total of 230 offline questionnaires were collected from students of Sungkyunkwan University in the Republic of Korea for the analysis (51.7 percent female; Mean age $=23.4$ ). University students are good survey respondents, as they are prominent consumers who use smartphones actively $[87,88]$, and have a higher intention to repurchase them in the near future [89]. Participants were undergraduate (98.7\%) and graduate $(1.3 \%)$ students with various majors at a large university in Seoul, Korea who used such Smartphones as the Samsung Smartphone (45.7\%), Apple iPhone (30.4\%), LG Smartphone (18.3) and others (5.6\%). Data were collected at two times. The first experiment was conducted from 1 November to 7 December 2018 and the second was operated from 4 to 13 December 2018. The demographic features of the survey participants are provided in Table 1.

Table 1. Demographic properties.

\begin{tabular}{|c|c|c|c|}
\hline \multicolumn{2}{|c|}{ Features } & \multirow{2}{*}{$\begin{array}{c}\text { Frequency } \\
119\end{array}$} & \multirow{2}{*}{$\begin{array}{c}\% \\
51.7 \%\end{array}$} \\
\hline Gender & Female & & \\
\hline Gender & Male & 111 & $48.3 \%$ \\
\hline \multirow{2}{*}{ Education } & Undergraduate & 227 & $98.7 \%$ \\
\hline & Graduate & 3 & $1.3 \%$ \\
\hline \multirow{4}{*}{ Smartphone Brand } & Samsung & 105 & $45.7 \%$ \\
\hline & Apple & 70 & $30.4 \%$ \\
\hline & LG & 42 & $18.3 \%$ \\
\hline & Others & 13 & $5.6 \%$ \\
\hline
\end{tabular}




\subsection{Measures}

All questionnaire items were adopted from relevant previous studies, as shown in Table 2. Each survey questions were measured on seven-point Likert scales that ranged from 1 (strongly disagree) to 7 (strongly agree). To ensure content validity, we refined and modified the original version of the questionnaire by conducting pilot tests before the experiment and confirmed that the items were unambiguous.

Table 2. Questionnaire.

\begin{tabular}{|c|c|c|c|}
\hline Construct & Avg; (SD) & Question & Source \\
\hline Emotional Appeal & $4.84(1.811)$ & $\begin{array}{l}\text { This advertising copy conveys more emotional } \\
\text { features than the functional features of the product. }\end{array}$ & \multirow{2}{*}{$\begin{array}{l}\text { Albers-Miller and } \\
\text { Stafford [29] }\end{array}$} \\
\hline Rational Appeal & $4.77(1.662)$ & $\begin{array}{l}\text { This advertising copy conveys more functional } \\
\text { features than the emotional features of the product. }\end{array}$ & \\
\hline \multirow{4}{*}{ Hedonic Value } & $3.97(1.754)$ & $\begin{array}{l}\text { It is fun to read product information through } \\
\text { advertising copy. }\end{array}$ & \multirow{8}{*}{ Lin and $\mathrm{Lu}[36]$} \\
\hline & 3.52 (1.677) & $\begin{array}{l}\text { Advertising copy gives me an enjoyable } \\
\text { expectation for the product. }\end{array}$ & \\
\hline & $3.48(1.684)$ & I enjoy reading advertising copy. & \\
\hline & $3.77(1.673)$ & I do not get bored by reading the advertising copy. & \\
\hline \multirow{4}{*}{ Utilitarian Value } & $3.74(1.736)$ & $\begin{array}{l}\text { Advertising copy enables me to acquire a large } \\
\text { amount of information about a product. }\end{array}$ & \\
\hline & $3.55(1.649)$ & $\begin{array}{l}\text { Advertising copy enhances my efficiency in } \\
\text { identifying information. }\end{array}$ & \\
\hline & $3.62(1.656)$ & $\begin{array}{l}\text { Advertising copy is a useful medium for obtaining } \\
\text { product information. }\end{array}$ & \\
\hline & $3.62(1.622)$ & $\begin{array}{l}\text { Advertising copy is a useful medium for } \\
\text { identifying a product. }\end{array}$ & \\
\hline \multirow{3}{*}{ Satisfaction } & $3.42(1.621)$ & $\begin{array}{l}\text { I feel satisfied with the information provided in the } \\
\text { advertising copy. }\end{array}$ & \multirow{3}{*}{$\begin{array}{l}\text { Gao, Wechter and } \\
\text { Bai [52] }\end{array}$} \\
\hline & $2.80(1.729)$ & $\begin{array}{l}\text { I feel content with the information provided in the } \\
\text { advertising copy. }\end{array}$ & \\
\hline & $3.10(1.573)$ & $\begin{array}{l}\text { I feel pleased with the information provided in the } \\
\text { advertising copy. }\end{array}$ & \\
\hline \multirow{3}{*}{ Affective Trust } & $3.97(1.495)$ & This advertising copy is likable. & \multirow{9}{*}{$\begin{array}{l}\text { Soh, Reid and King } \\
\text { [48] }\end{array}$} \\
\hline & $3.31(1.492)$ & This advertising copy is enjoyable. & \\
\hline & $4.99(1.345)$ & This advertising copy is positive. & \\
\hline \multirow{6}{*}{ Cognitive Trust } & $4.25(1.306)$ & This advertising copy is truthful. & \\
\hline & $4.23(1.293)$ & This advertising copy is credible. & \\
\hline & $4.23(1.327)$ & This advertising copy is reliable. & \\
\hline & $3.91(1.371)$ & This advertising copy is dependable. & \\
\hline & $3.88(1.381)$ & This advertising copy is accurate. & \\
\hline & $4.08(1.455)$ & This advertising copy is useful. & \\
\hline \multirow{3}{*}{ Positive WOM } & $3.52(1.435)$ & $\begin{array}{l}\text { I am willing to recommend the product in } \\
\text { advertising to others. }\end{array}$ & \multirow{3}{*}{ Choi and Choi [63] } \\
\hline & $3.89(1.510)$ & $\begin{array}{l}\text { I usually say positive things about the product in } \\
\text { advertising to others. }\end{array}$ & \\
\hline & $3.47(1.506)$ & $\begin{array}{l}\text { I will tell my friends and relatives to use the } \\
\text { product in advertising to others. }\end{array}$ & \\
\hline
\end{tabular}

\subsection{Procedure and Statistical Analysis}

Before conducting our survey, we presented the participants with two types of stimuli for thirty seconds using modified advertising copies, excluding brand and product names, adopted from smartphone manufacture in the Republic of Korea that consisted of five emotional and rational phrases, respectively. The stimuli developed measured the degree of advertising appeal using the scale of Rosselli, et al. [90]. By providing these stimuli, participants' perceptions and attitudes could be shaped 
based on judgments drawn from external stimuli immediately without investing significant cognitive effort, while participants adopt a rational and systematic approach to collect evidence that confirms the reliability, credibility, and competence of the information that they process [13]. The emotional copies included advertising copies such as "The friend who shares my life beside me" (see Figure 2).

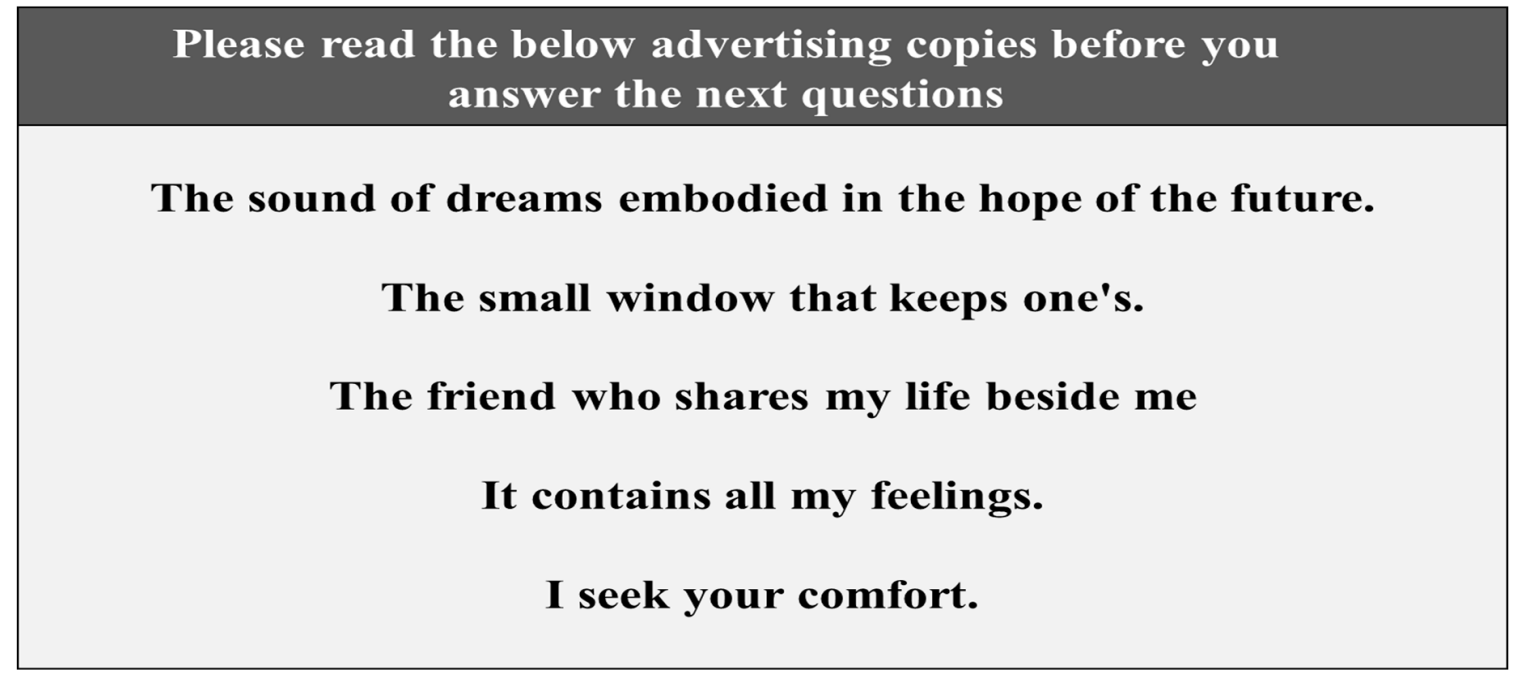

Figure 2. Stimuli using advertising copy for emotional appeal.

The rational copies included advertising copies such as "The combination of cutting-edge technology and practicality" (see Figure 3). We confirmed their statistical difference's significance by performing two-sample $t$-tests $(p<0.01)$. Next, we conducted PLS-SEM [91] to test the hypotheses proposed and performed the PLS-POS analysis to explore the unobserved heterogeneity in the sample data using SmartPLS 3.0 (SmartPLS GmbH, Boenningstedt, Germany, https://www.smartpls.com). SmartPLS 3.0 provides PLS prediction-oriented segmentation (PLS-POS), a distance-based approach, that provides an explicit PLS-specific criterion to discover unobserved heterogeneity from the PLS-SEM $[77,92,93]$. Then, we conducted additional hypothesis tests for the heterogeneous data groups according to the PLS-POS analysis results.

\section{Please read the below advertising copies before you answer the next questions}

The combination of cutting-edge technology and practicality.

Faster interface than the others.

Your smart assistant.

The device that changes your life quickly and comfortably.

The world's core technology cluster.

Figure 3. Stimuli using advertising copy for rational appeal. 


\section{Results}

Before we conduct the evaluation of our structural equation model, we first, verified the fundamental criteria, such as the common method bias. In order to confirm a common-method bias on the data sample of this research that may be possible to occur due to the self-reported survey, we have conducted the single-factor test [94]. The test result presented that only one factor explained $23.4 \%$ of the variance. Since the result of the one-factor test is less than $50 \%$, we could presume that there was no significant impact of common-method bias in the data sample [94-96].

Next, the reliability and validity were assessed. As shown in Table 3, Cronbach's $\alpha$ scores varied from 0.833 to 0.950 , apart from the emotional appeal and rational appeal that had only one survey item, presented the inner consistency of the model, [97]. Furthermore, composite reliability scores and the average variance extracted (AVE) [97] ranged from 0.900 to 0.964 and from 0.752 to 0.879 , excluding emotional appeal and rational appeal constructs, respectively, were as well assessed to verify the convergent validity. The variance is all larger than 0.5 , as Table 3 indicates with the findings [98]. Note that the statistical results of reliability and validity for two experiment-based constructs, emotional appeal and rational appeal, showed all 1.000 because there was only one item with one stimulus for each construct.

Table 3. Reliability and Validity of the First-order Constructs.

\begin{tabular}{cccc}
\hline Construct & Cronbach's $\alpha$ & Composite Reliability & AVE \\
\hline Emotional Appeal & 1.000 & 1.000 & 1.000 \\
Rational Appeal & 1.000 & 1.000 & 1.000 \\
Hedonic Value & 0.937 & 0.955 & 0.841 \\
Utilitarian Value & 0.950 & 0.964 & 0.869 \\
Satisfaction & 0.882 & 0.927 & 0.808 \\
Affective Trust & 0.833 & 0.900 & 0.752 \\
Cognitive Trust & 0.935 & 0.950 & 0.761 \\
Positive WOM & 0.931 & 0.956 & 0.879 \\
\hline
\end{tabular}

Then, we conducted the Fornell-Larcker criterion to appraise discriminant validity for the research model. The evaluation results provided, as presented in Table 4, the AVE scores of the constructs were more significant than the other constructs under the diagonal line, confirmed discriminant validity [97].

Table 4. Discriminant validity.

\begin{tabular}{ccccccccc}
\hline Construct & EA & RA & HV & UV & SA & AT & CT & PW \\
\hline EA & 1.000 & & & & & & & \\
RA & -0.146 & 1.000 & & & & & & \\
HV & 0.412 & 0.219 & 0.917 & & & & & \\
UV & 0.194 & 0.514 & 0.720 & 0.932 & & & & \\
SA & 0.280 & 0.373 & 0.761 & 0.789 & 0.899 & & & \\
AT & 0.392 & 0.150 & 0.746 & 0.588 & 0.708 & 0.867 & & \\
CT & 0.163 & 0.429 & 0.607 & 0.659 & 0.644 & 0.624 & 0.872 & \\
PW & 0.147 & 0.349 & 0.633 & 0.620 & 0.654 & 0.627 & 0.665 & 0.938 \\
\hline
\end{tabular}

Note: EA is emotional appeal; RA is rational appeal; $\mathrm{HV}$ is hedonic value; $\mathrm{UV}$ is utilitarian value; $\mathrm{SA}$ is satisfaction; $\mathrm{AT}$ is affective trust; $\mathrm{CT}$ is cognitive trust; $\mathrm{PW}$ is positive WOM.

In addition, we assessed the heterotrait-monotrait (HTMT) ratio in order to validate the research model rigorously. Table 5 demonstrated that the HTMT ratio evaluation results were less significant than 1.00, as recommended by Henseler, et al. [99]. 
Table 5. HTMT ratio for discriminant validity.

\begin{tabular}{ccccccccc}
\hline Construct & EA & RA & HV & UV & SA & AT & CT & PW \\
\hline EA & & & & & & & & \\
RA & 0.146 & & & & & & & \\
HV & 0.426 & 0.226 & & & & & & \\
UV & 0.199 & 0.527 & 0.763 & & & & & \\
SA & 0.301 & 0.402 & 0.835 & 0.864 & & & & \\
AT & 0.432 & 0.163 & 0.840 & 0.656 & 0.812 & & & \\
CT & 0.169 & 0.446 & 0.649 & 0.700 & 0.708 & 0.705 & & \\
PW & 0.151 & 0.363 & 0.677 & 0.660 & 0.718 & 0.712 & 0.712 & \\
\hline
\end{tabular}

Note: EA is emotional appeal; RA is rational appeal; $\mathrm{HV}$ is hedonic value; UV is utilitarian value; $\mathrm{SA}$ is satisfaction; $\mathrm{AT}$ is affective trust; $\mathrm{CT}$ is cognitive trust; $\mathrm{PW}$ is positive WOM.

\subsection{Assessing the Global Model}

In connection with Consumers' psychological traits advertising appeals for sustainable marketing, Hypothesis 1 and 2 found that emotional appeal and rational appeal had significant positive influences on hedonic value $(\beta=0.412, p<0.000$, t-value $=6.960)$ and utilitarian value $(\beta=0.514, p<0.000$, $\mathrm{t}$-value $=10.588)$, respectively. Next, the test results of Hypotheses $3 \mathrm{a}$ and $3 \mathrm{~b}$ both presented that hedonic value positively influenced affective trust $(\beta=0.402, p<0.000$, $\mathrm{t}$-value $=7.326)$ and satisfaction $(\beta=0.494, p<0.000$, t-value $=7.290)$, respectively. Likewise, utilitarian value, Hypotheses $4 \mathrm{a}$ and $4 \mathrm{~b}$ also showed significant positive impacts on both satisfaction $(\beta=0.500, p<0.000$, t-value $=8.975)$ and cognitive trust $(\beta=0.401, p<0.000$, $\mathrm{t}$-value $=5.228)$. Furthermore, aligned with Hypotheses $5 \mathrm{a}$ and $5 \mathrm{~b}$, satisfaction showed positive influences on both affective trust $(\beta=0.332, p<0.000$, t-value $=4.879)$ and cognitive trust $(\beta=0.328, p<0.000$, $\mathrm{t}$-value $=4.331)$, respectively. Lastly, satisfaction (Hypothesis 6 , $\beta=0.277, p<0.000$, t-value $=3.138$ ), affective trust (Hypothesis $7, \beta=0.208, p<0.000$, $\mathrm{t}$-value $=3.307$ ) and cognitive trust (Hypothesis $8, \beta=0.357, p<0.000, \mathrm{t}$-value $=4.752$ ) all significantly positively influenced positive WOM. Figure 4 and Table 6 below recapitulate the overall results of the global structural equation model assessment for the Hypotheses of this research. Note that the standardized root mean square residual (SRMR) value of the model showed a good fit with 0.056 , which is less than 0.08 [100].

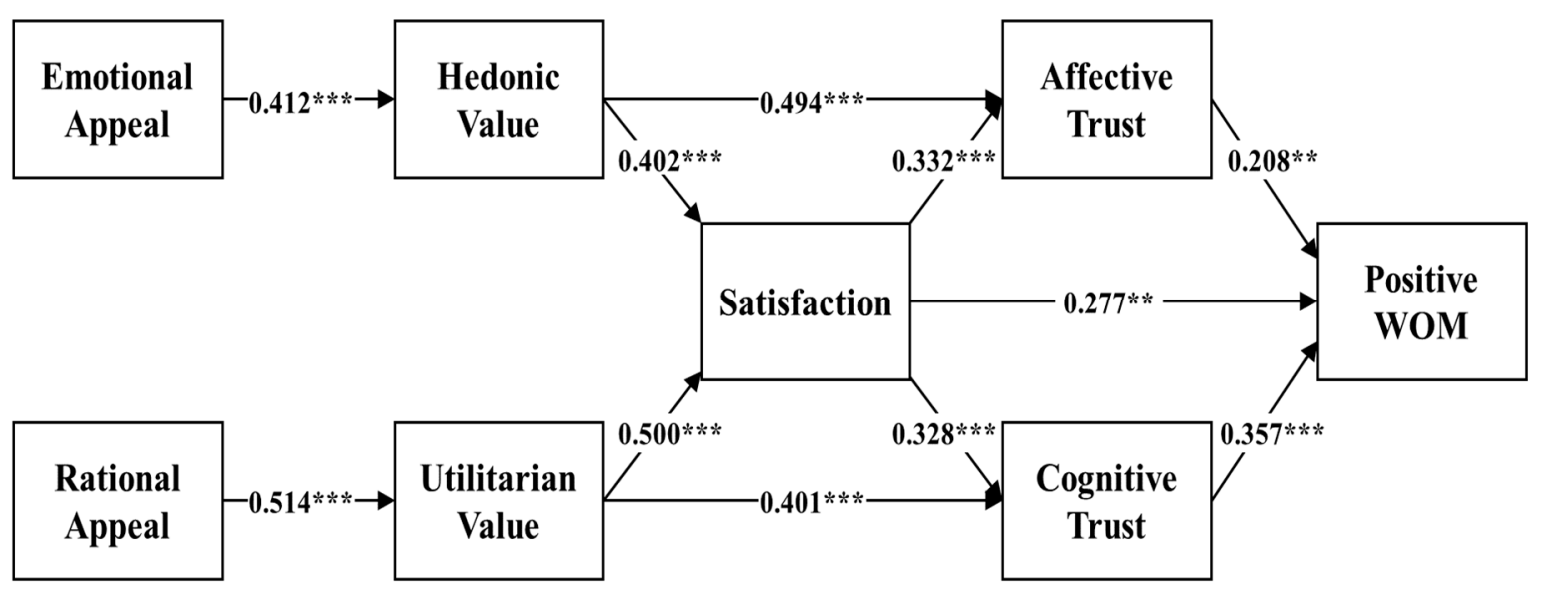

Figure 4. Results of PLS-SEM hypothesis testing on the global model $\left.{ }^{* *} p<0.01,{ }^{* * *} p<0.001\right)$. 
Table 6. Overall, Results of Hypotheses Tests.

\begin{tabular}{|c|c|c|}
\hline & Hypothesis & Results \\
\hline H1 & \multirow{3}{*}{$\begin{array}{l}\text { Emotional ad appeal will positively influence hedonic value. } \\
\text { Rational ad appeal will positively influence utilitarian value. } \\
\text { Hedonic value will positively influence affective trust (H3a) } \\
\text { and satisfaction (H3b). }\end{array}$} & Accepted \\
\hline $\mathrm{H} 2$ & & Accepted \\
\hline H3 & & Accepted \\
\hline $\mathrm{H} 4$ & $\begin{array}{l}\text { Utilitarian value will positively influence cognitive trust } \\
\qquad(\mathrm{H} 4 \mathrm{a}) \text { and satisfaction (H4b). }\end{array}$ & Accepted \\
\hline H5 & $\begin{array}{l}\text { Satisfaction will positively influence affective trust (H5a) and } \\
\text { cognitive trust (H5b). }\end{array}$ & Accepted \\
\hline H6 & Satisfaction will positively influence positive WOM. & Accepted \\
\hline H7 & Affective trust will positively influence positive WOM. & Accepted \\
\hline $\mathrm{H} 8$ & Cognitive trust will positively influence positive WOM. & Accepted \\
\hline
\end{tabular}

\subsection{Discovering the Hidden Consumers' Traits}

After the global model analysis, we steered a PLS-POS method to examine the hidden heterogeneity in the data sample. PLS-POS is an approach known well to measure heterogeneity not observed in PLS models by segmenting the sample data without the need for an a priori variable (i.e., gender, age, etc.) and is deemed a suitable method for predictive-oriented segmentation analysis $[77,101]$.

We followed the guidelines of Becker, Rai, Ringle and Völckner [77] to calculate the result for the numbers $(K)$ of segmented groups. The original sample data segmented from two groups $(K=2)$, which is the first number of predefined groups. The iterative segmenting process was performed by increasing the number until the data separated into the groups that meet the minimum sample size requirement $(10 \%)$ of PLS-POS segmentation. In this study, when subdivided into four groups $(K=4)$, the smallest group $(6.1 \%)$ did not meet the requirement of $10 \%$. The criterion for selecting the optimal number $(K)$ of segmented groups is the average of the constructs' variance explained $\left(R^{2}\right)$. As a result, we obtained three-segmented groups $(K=3)$, because the average $R^{2}$ was highest in the groups (see Table 7).

Table 7. PLS-POS results for segment retention criteria.

\begin{tabular}{cccccccccccc}
\hline Construct & Original $\boldsymbol{R}^{2}$ & \multicolumn{2}{c}{$\boldsymbol{K}=\mathbf{2}$} & \multicolumn{3}{c}{$\boldsymbol{K = 3}$} \\
\hline HV & 0.170 & 0.329 & 0.101 & 0.247 & 0.345 & 0.019 & 0.136 & 0.531 & 0.038 & 0.500 \\
UV & 0.264 & 0.455 & 0.165 & 0.272 & 0.157 & 0.359 & 0.345 & 0.173 & 0.066 & 0.619 \\
AT & 0.603 & 0.768 & 0.521 & 0.567 & 0.735 & 0.550 & 0.746 & 0.860 & 0.425 & 0.766 \\
CT & 0.475 & 0.893 & 0.231 & 0.635 & 0.546 & 0.334 & 0.715 & 0.686 & 0.161 & 0.708 \\
SA & 0.700 & 0.719 & 0.694 & 0.673 & 0.696 & 0.752 & 0.821 & 0.854 & 0.589 & 0.731 \\
PW & 0.516 & 0.780 & 0.336 & 0.766 & 0.809 & 0.793 & 0.844 & 0.957 & 0.422 & 0.653 \\
$\sum R^{2}$ & 2.728 & \multicolumn{2}{c}{2.996} & & 3.086 & & & 3.337 & \\
Segment Size & 230 & 74 & 156 & 68 & 74 & 88 & 60 & 14 & 97 & 59 \\
Relative Size & $100 \%$ & $32.2 \%$ & $67.8 \%$ & $29.6 \%$ & $32.2 \%$ & $38.3 \%$ & $26.1 \%$ & $6.1 \% *$ & $42.2 \%$ & $25.7 \%$ \\
\hline
\end{tabular}

Note: EA is emotional appeal; RA is rational appeal; HV is hedonic value; UV is utilitarian value; $\mathrm{SA}$ is satisfaction; AT is affective trust; $\mathrm{CT}$ is cognitive trust; $\mathrm{PW}$ is positive WOM; $\mathrm{K}=$ number of predefined segmented group; * $6.1 \%$ does not meet the minimum sample size requirement of the PLS-POS segmentation; therefore, ' $K=3^{\prime}$ segmentation was finally adopted.

\subsection{Identifying Different Types of Smartphone Consumers}

Table 8 provides the descriptive statistics and Pearson correlations for all variables and shows that all were related to each other significantly. The hypothesis tests for the global model performed with the entire dataset showed further that all of the hypotheses proposed were supported statistically. 
Table 8. Descriptive statistics and correlations for the variables.

\begin{tabular}{|c|c|c|c|c|c|c|c|c|c|c|c|c|}
\hline Construct & $\mathbf{M}$ & SD & AVE & CR & EA & RA & HV & UV & SA & AT & CT & PW \\
\hline EA & 4.839 & 1.811 & 1.000 & 1.000 & 1.000 & & & & & & & \\
\hline RA & 4.770 & 1.662 & 1.000 & 1.000 & $-0.146 *$ & 1.000 & & & & & & \\
\hline $\mathrm{HV}$ & 3.692 & 1.555 & 0.955 & 0.841 & $0.419^{* *}$ & $0.226^{* *}$ & 1.000 & & & & & \\
\hline UV & 3.630 & 1.553 & 0.964 & 0.869 & $0.194^{* *}$ & $0.515^{* *}$ & $0.719 * *$ & 1.000 & & & & \\
\hline SA & 3.107 & 1.476 & 0.927 & 0.808 & $0.284^{* *}$ & $0.380^{* *}$ & $0.755^{* *}$ & $0.792 * *$ & 1.000 & & & \\
\hline AT & 4.093 & 1.253 & 0.900 & 0.752 & $0.393 * *$ & $0.149 *$ & $0.743^{* *}$ & $0.585^{* *}$ & $0.695^{* *}$ & 1.000 & & \\
\hline CT & 4.102 & 1.173 & 0.950 & 0.761 & $0.166^{*}$ & $0.436^{* *}$ & $0.607^{* *}$ & $0.661^{* *}$ & $0.645^{* *}$ & $0.624^{* *}$ & 1.000 & \\
\hline PW & 3.628 & 1.391 & 0.956 & 0.879 & $0.145^{*}$ & $0.351 * *$ & $0.629^{* *}$ & $0.619^{* *}$ & $0.648^{* *}$ & $0.626^{* *}$ & $0.664^{* *}$ & 1.000 \\
\hline
\end{tabular}

Note: * $p<0.05,{ }^{* *} p<0.01 ; \mathrm{M}$ is mean; $\mathrm{SD}$ is standard deviation; $\mathrm{AVE}$ is average variance extracted; $\mathrm{CR}$ is composite reliabilities; to ensure discriminant validity, diagonal values should be greater than the off-diagonal elements.

Next, we conducted additional hypothesis tests on the three-segmented groups, including the comparison with the global model. The significant statistical differences between the segmented groups are displayed visually in Figures $5-7$. Based on these results, we classified the three consumers typologies that the results helped reveal in the unobserved consumer segments as Type $1(n=68)$, Type $2(n=74)$ and Type $3(n=88)$.

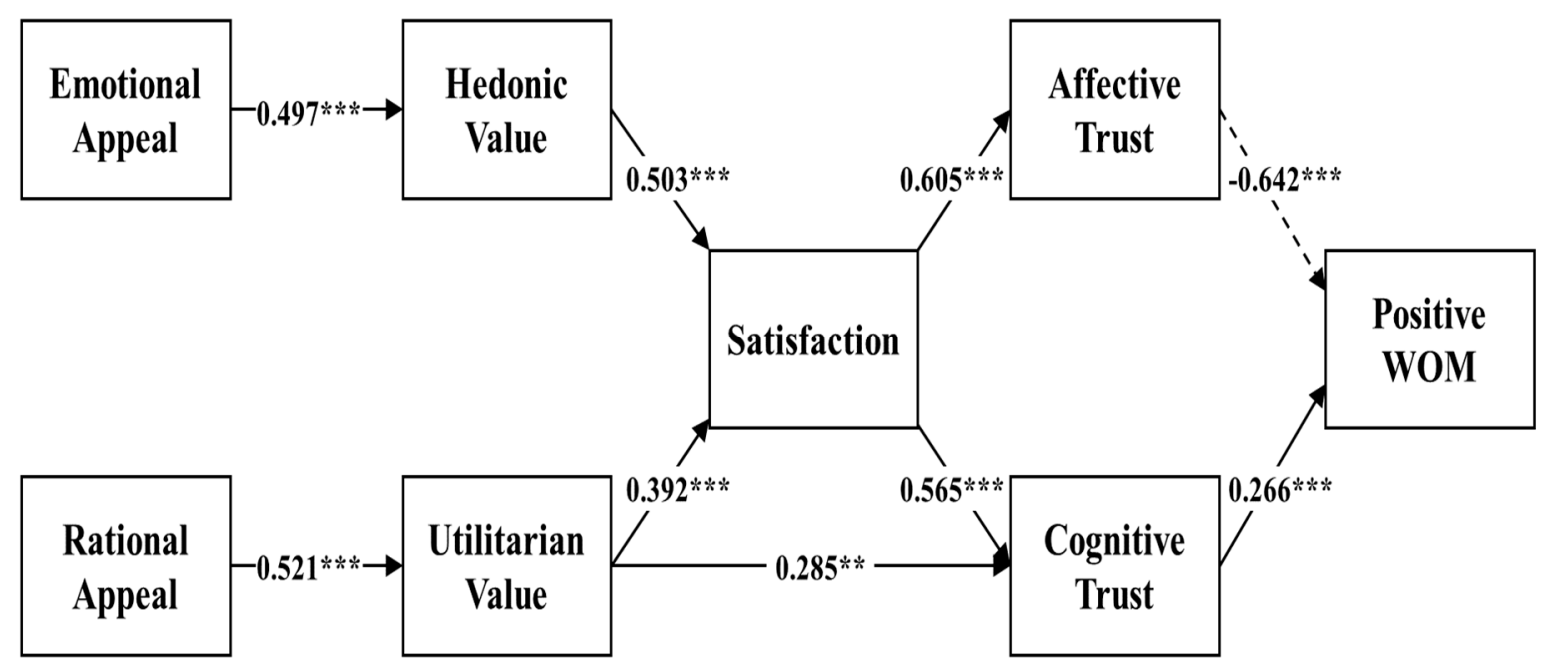

Figure 5. PLS-POS Type 1 model $\left(n=68 ;{ }^{* *} p<0.01,{ }^{* * *} p<0.001\right.$; the solid line indicates positive statistical significance; the dotted line indicates negative statistical significance; no link indicates statistical insignificance).

First, in the Type 1 model $(n=68)$, Hypotheses H1 (emotional appeal $\rightarrow$ hedonic value), $\mathrm{H} 2$ (rational appeal $\rightarrow$ utilitarian value), H3b (hedonic value $\rightarrow$ satisfaction), H5a (satisfaction $\rightarrow$ affective trust), $\mathrm{H} 5 \mathrm{~b}$ (satisfaction $\rightarrow$ cognitive trust), $\mathrm{H} 6$ (satisfaction $\rightarrow$ positive WOM), $\mathrm{H} 8$ (cognitive trust $\rightarrow$ positive WOM) were accepted similarly to the global model. However, $\mathrm{H3a}$ (hedonic value $\rightarrow$ affective trust) was rejected, while H7 (affective trust $\rightarrow$ positive WOM) showed a significant negative influence that was the opposite result to the global models (See Figure 5).

Next, in the Type 2 model ( $n=74)$, Hypotheses H1, H2, H3b, H4a, H4b, H5a, H6 were accepted as the global model and the Type 1 model presented. However, H3a (hedonic value $\rightarrow$ affective trust) and H7 (affective trust $\rightarrow$ positive WOM) were also accepted that were rejected with the Type 1 model, while H5b was rejected that was accepted by the global model and the Type 1 model. In addition, H8 (affective trust $\rightarrow$ positive WOM) showed a reverse result, the significant negative impact, comparing to the global model and the Type 1 model (See Figure 6). 


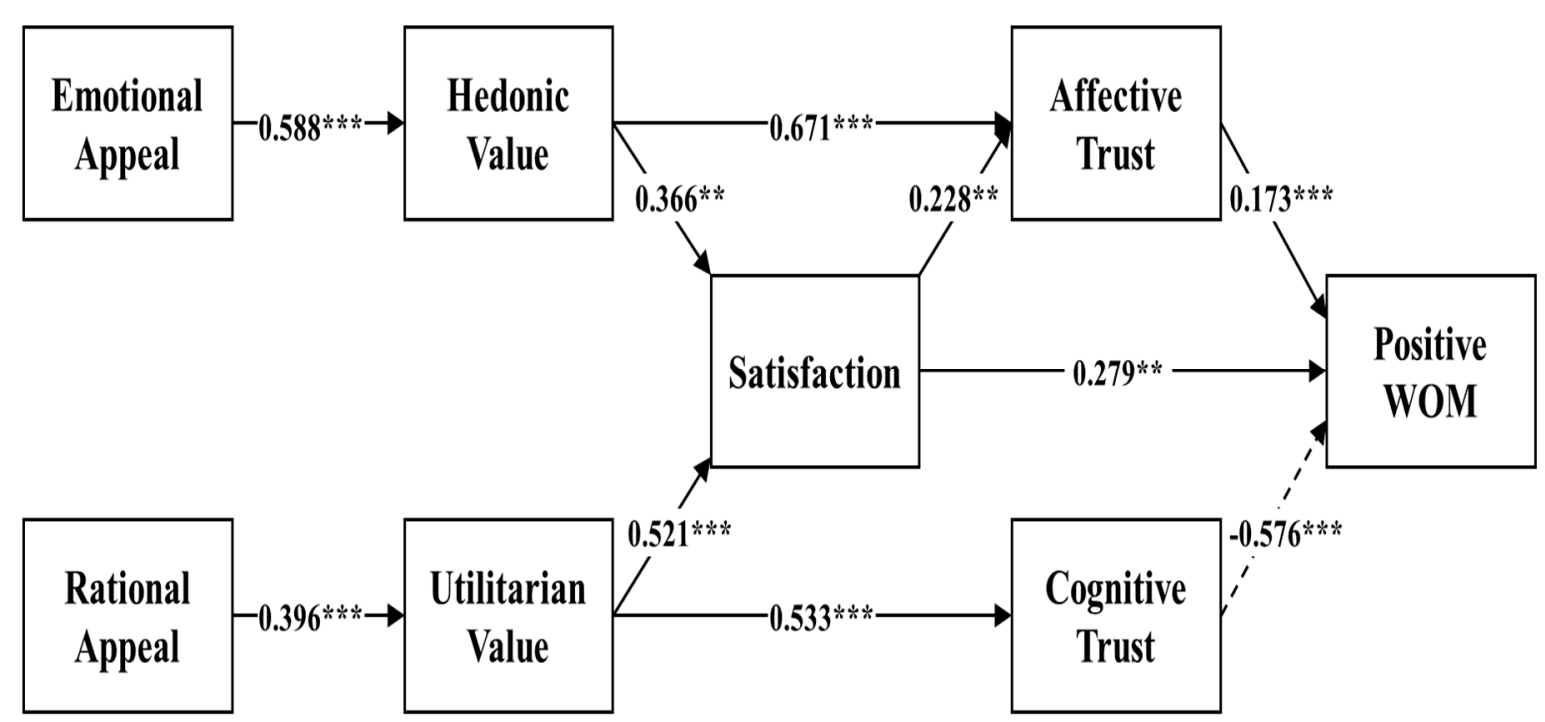

Figure 6. PLS-POS Type 2 model $\left(n=74 ;{ }^{* *} p<0.01,{ }^{* * *} p<0.001\right.$; the solid line indicates positive statistical significance; the dotted line indicates negative statistical significance; no link indicates statistical insignificance).

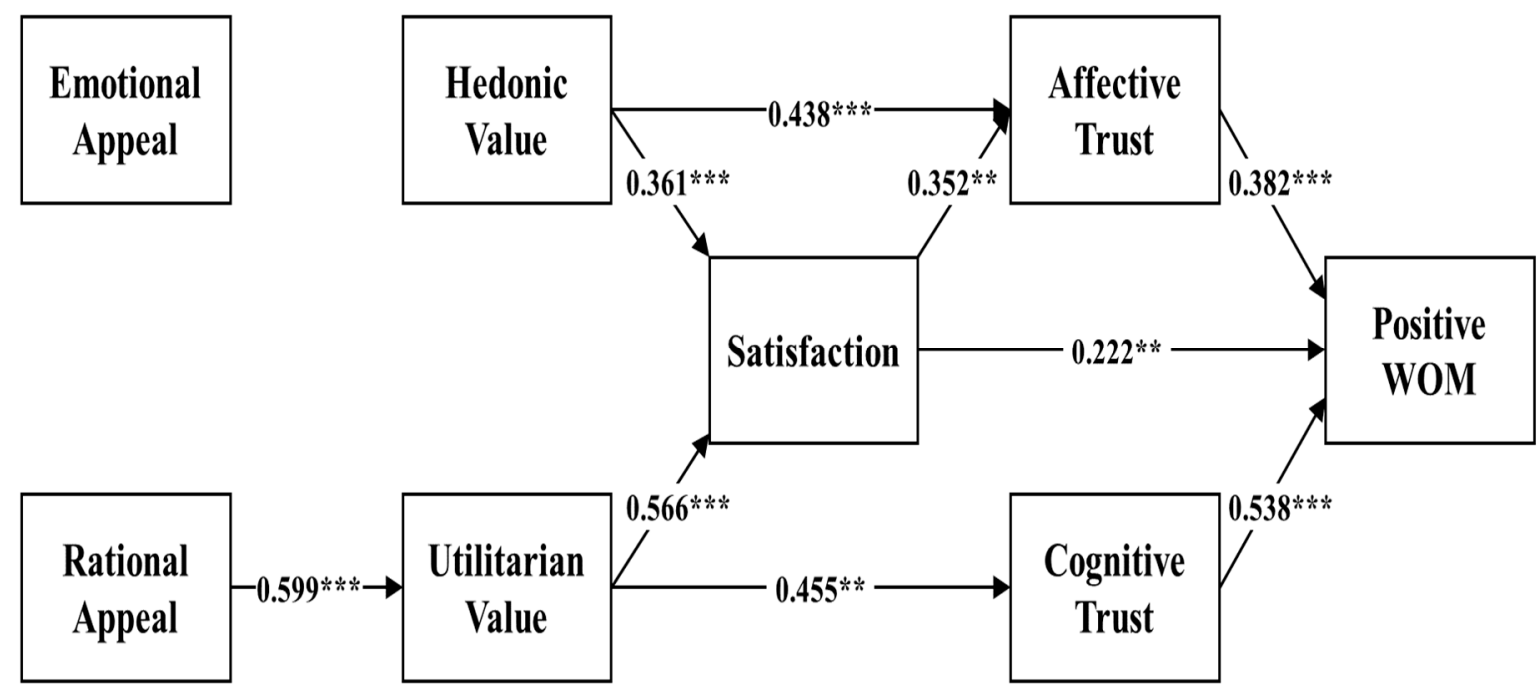

Figure 7. PLS-POS Type 3 model $\left(n=88 ;{ }^{* *} p<0.01,{ }^{* * *} p<0.001\right.$; the solid line indicates positive statistical significance; the dotted line indicates negative statistical significance; no link indicates statistical insignificance).

Lastly, the Type 3 model $(n=8)$ presented fairly dissimilar results than the other models. In this model, Hypotheses H2, H3a, H3b, H4a, H4b, H5a, H6, H7 and H8 were accepted. Nevertheless, $\mathrm{H} 1$ (emotional appeal $\rightarrow$ hedonic value) and $\mathrm{H} 5 \mathrm{~b}$ (satisfaction $\rightarrow$ cognitive trust) were rejected (See Figure 7).

The overall results showed that there were statistically significant differences between the groups, including the entire sample (see Table 9). 
Table 9. Overall, Results of Hypothesis Tests for All Groups.

\begin{tabular}{|c|c|c|c|c|}
\hline Hypothesis & $\begin{array}{l}\text { Global Model } \\
\quad(\mathrm{N}=230)\end{array}$ & $\begin{array}{c}\text { Type } 1 \text { Model } \\
\quad(\mathrm{N}=68)\end{array}$ & $\begin{array}{c}\text { Type } 2 \text { Model } \\
(\mathrm{N}=74)\end{array}$ & $\begin{array}{c}\text { Type } 3 \text { Model } \\
\text { (N = 88) }\end{array}$ \\
\hline H1. EA $\rightarrow$ HV & $0.412 * * *$ & $0.497^{* * *}$ & $0.588^{* * *}$ & 0.138 \\
\hline H2. RA $\rightarrow$ UV & $0.514^{* * *}$ & $0.521^{* * *}$ & $0.396^{* * *}$ & $0.599^{* * *}$ \\
\hline H3a. HV $\rightarrow$ AT & $0.494^{* * *}$ & 0.181 & $0.671^{* * *}$ & $0.438^{* * *}$ \\
\hline H3b. HV $\rightarrow$ SA & $0.402 * * *$ & $0.503^{* * *}$ & $0.366^{* *}$ & $0.361^{* * *}$ \\
\hline H4a. UV $\rightarrow$ CT & $0.401^{* * *}$ & $0.285^{* *}$ & $0.533^{* * *}$ & $0.455^{* *}$ \\
\hline H3b. UV $\rightarrow$ SA & $0.500^{* * *}$ & $0.392 * * *$ & $0.521^{* * *}$ & $0.566^{* * *}$ \\
\hline H5a. SA $\rightarrow$ AT & $0.332^{* * *}$ & $0.605^{* * *}$ & $0.228^{* *}$ & $0.352^{* *}$ \\
\hline H5b. SA $\rightarrow$ CT & $0.328^{* * *}$ & $0.565^{* * *}$ & 0.240 & 0.063 \\
\hline H6. SA $\rightarrow$ PW & $0.277^{* *}$ & 0.044 & $0.279 * *$ & $0.222 * *$ \\
\hline H7. AT $\rightarrow$ PW & $0.208^{* *}$ & $-0.642^{* * *}$ & $0.173^{* * *}$ & $0.382^{* * *}$ \\
\hline H8. CT $\rightarrow$ PW & $0.357^{* * *}$ & $0.266^{* * *}$ & $-0.576^{* * *}$ & $0.538^{* * *}$ \\
\hline H9. UH & \multicolumn{4}{|c|}{ Accepted } \\
\hline
\end{tabular}

Note: ${ }^{* *} p<0.01,{ }^{* * *} p<0.001$; EA is emotional appeal; RA is rational appeal; HV is hedonic value; UV is utilitarian value; SA is satisfaction; AT is affective trust; CT is cognitive trust; PW is positive WOM; UH is unobserved heterogeneity.

\section{Discussion}

In this study, we explored in detail the role of emotional and rational appeals and hidden heterogeneity of consumers in advertising copies for sustainable marketing based on the framework of advertising appeal-value-satisfaction-trust-positive WOM. Based on the global model analysis with PLS-SEM, we found support for the positive impacts of all the relationships between constructs that we have proposed. Emotional appeal and rational appeal positively influenced on hedonic value $(\mathrm{t}$-value $=6.960)$ and utilitarian value $(\mathrm{t}$-value $=10.588)$, respectively, as Adaval [39] and Geuens, De Pelsmacker and Faseur [40] argued. These results proved that consumers' emotional confirmation in the advertisement copies had a significant impact on hedonic criteria, while rational evidence in the advertising copies could significantly influence utilitarian value.

Hedonic value had strong influence to both affective trust ( $\mathrm{t}$-value $=7.326)$ and satisfaction $(\mathrm{t}$-value $=7.290)$ and utilitarian value also significantly affected both satisfaction $(\mathrm{t}$-value $=8.975)$ and cognitive trust ( $t$-value $=5.228$ ) as Chai, Malhotra and Alpert [49] suggested. These outcomes showed that the interrelationship of value, trust and satisfaction and disclosed that developing providing hedonic value to consumers would increase affective trust and satisfaction. In contrast, utilitarian value delivery would enhance consumers' cognitive trust and satisfaction. Meanwhile, satisfaction also had substantially positive influences on affective trust $(\mathrm{t}$-value $=4.879)$, cognitive trust $(\mathrm{t}$-value $=4.331)$ and positive WOM ( $\mathrm{t}$-value $=3.138$ ), as Sanchez-Franco [53], Kampen, De Walle and Bouckaert [55] and Maxham III [71] proposed. We could argue that consumers' retention of satisfaction from advertising copies were the determinants of trust and positive WOM derived from the results.

As Alfina, Ero, Hidayanto and Shihab [76] and Xu [75] suggested, positive WOM was affected by both $(\mathrm{t}$-value $=3.307)$ and cognitive trust $(\mathrm{t}$-value $=4.752)$. Based on the results, we could imply that the greater cognitive trust of consumers in advertising copies would bring a more significant impact on positive WOM, while a higher degree of consumers' cognitive trust in advertising copies would bring more positive WOM credibility.

When we utilized an unobserved heterogeneity assessment, we uncovered unique discoveries within the data sample. For instance, in the Type 1 model $(n=68)$, the influences of hedonic value on affective trust and satisfaction on positive WOM were no more profound. In addition, the positive impact of affective trust on positive WOM in the global model changed to a negative influence ( $\beta=-0.642, p<0.000)$ prevailing in the Type 1 model. In addition, the initially positive influences of cognitive trust on positive WOM was reversed into a negative influence $(\beta=-0.576, p<0.000)$, while there was no influence of satisfaction on cognitive trust in the Type 2 model, suggesting that cognitive trust and satisfaction in advertising copies are diverse. In the Type 3 model, we discovered that 
positive effects of emotional appeal on hedonic value and satisfaction on cognitive trust were no longer meaningful, suggesting that there were specific unobserved heterogeneous traits of consumers toward advertising copies. The results of our study on unobserved heterogeneity hint that there are hidden traits of consumers that cannot be found with a conventional statistical approach; thus, firms should consider more holistically, including potential elements in advertising copies that could satisfy consumers' hidden insights to achieve sustainable marketing with the fulfillment of consumer needs, attainment of firms' goal and securing the process competitiveness in the market, as Fuller [11] argued.

\section{Conclusions}

From the test results of the proposed hypotheses, we revealed that there were significant relationships between appeal, value, trust, satisfaction and positive WOM in the global model for advertising copies. More specifically, emotional and rational advertising appeals positively influenced hedonic and utilitarian values, and these two values had impacts on trust and satisfaction of smartphone consumers. Also, similar to Koh and Sundar [50] suggested, utilitarian features (i.e., product information) could generate cognitive trust, while hedonic features (i.e., enjoyment) could engender affective trust. Furthermore, the affective and cognitive trust and satisfaction of consumers in advertising copies could be critical rationales for positive WOM in the context of smartphone sales.

In addition to the global model analysis, in three consumer typology models, the Type 1 model had the characteristics of consumers with a rational orientation. This group's affective trust affected positive WOM negatively, which implies they were less likely to make positive comments about products or services in advertising copies. This phenomenon could be interpreted that even if they indicated strong trust in a product advertised, emotional terms, such as "likable," "enjoyable," and "positive" were construed damagingly due to their rational oriented characteristics. In contrast, we found that another participant group negatively perceived rational terms in advertising copy, such as "truthful," "credible," "reliable," "dependable," "accurate," and "useful," that would make them be unlikely to offer positive WOM. These were classified as Type 2 consumers, for example, those with an emotionally oriented. Lastly, some participants failed to perceive any hedonic value in the advertising's emotional appeal. In addition, they may not have developed cognitive trust even though they were satisfied with the advertising copies for products or services. Because their decisions on making positive WOM were related weakly to emotional stimuli and cognitive beliefs, they were categorized as Type 3 consumers, i.e., those with the utilitarian value orientation.

According to our results, marketers need to more minutely understand the effect of emotional and rational appeals that the advertising copies provide to the three different types of smartphone consumers for preparing a more sustainable marketing strategy. Moreover, advertising strategies that ignore such hidden heterogeneous characteristics would not only be ineffective, but also will lead to severe failure to implement marketing sustainability due to waste of resources such as time, cost and human resources. Instead, using the consumer behavioral strategical methods, such as target marketing that expose specific smartphone consumers with similar decision patterns, could provide a keystone for sustainable marketing as well as more increased marketing ROI.

For the field practitioners of smartphone manufacturers in the current competitive market, this research has the following implications. First, it sheds light on the prospective implementation of emotional and rational appeals within advertising copies, which would finally derive positive WOM through perceived value, trust and satisfaction that could help firms meet the requirements of sustainable marketing. Practitioners engaged in the smartphone market, the findings from this research also delivered vital information for pushing forward with the impending adoption of the appeal-value-trust-satisfaction-WOM framework for their sustainable marketing strategy. It implies that adequate elements, such as hedonic value, utilitarian value, satisfaction, affective trust and cognitive trust, on each stage should be presented to induce consumers to establish loyalty for the products and services with positive WOM. 
The unobserved heterogeneous characteristics of consumers indicated that the diversity of consumers should be carefully considered. Some consumers were in favor of rational confirmation, and some were emotional confirmation. As a sustainable marketing strategy, including the creation stage of advertising copies, these consumer characteristics need to be applied in order to provide adequate information to consumers, for example, if the products possess rational benefits, such as everyday goods, advertising copies should not emphasize on emotional appeal for consumers those in Type 1 model. On the other hand, forcing consumers, such as those in Type 3 model, who show high utilitarian orientation traits and prefer more hedonic value than utilitarian value to engage in advertising copies may cause them to refuse to have positive WOM. We recommend that the foundation of these ideas should be performed in earlier stages of formulating advertising copies to target the appropriate consumer segment for sustainable marketing.

This study provided contributions including in-depth considerations for managers of advertising and marketing companies and understanding to fill the gaps in smartphone consumer typology research as well for sustainable marketing. However, despite the implications as stated above, there still are limits in this research as follows. First, this study only used a cross-sectional self-reported dataset with a relatively small sample size of the survey participant. These data sample could be putatively susceptible to general method variance [96]. In order to alleviate the bias, adopting a longitudinal data sample with a larger sample size should be considered. Likewise, the implication of this research would have theoretically more philosophical generalizability with longitudinal datasets that could be implemented to not only smartphone consumers in Korea, but also various products or services in several countries. For more robust sustainable marketing strategies, future research needs to adopt non-cross-sectional datasets and broaden the range of topics compatible with advertising copies from the perspective of various types of consumers. If future research considers these suggestions, more fruitful contributions would be established that was not made in this research.

Author Contributions: Conceptualization, K.C.L., H.G.J. and C.K.; methodology, K.C.L., H.G.J. and C.K.; software, C.K. and H.G.J.; validation, C.K. and H.G.J.; formal analysis, C.K. and H.G.J.; investigation, C.K., H.G.J. and K.C.L.; data curation, C.K. and H.G.J.; writing-original draft preparation, C.K. and H.G.J.; writing-review and editing, C.K. and K.C.L.; supervision, K.C.L. All authors have read and agreed to the published version of the manuscript.

Funding: This research received no external funding.

Conflicts of Interest: The authors declare no conflict of interest.

\section{References}

1. Williams, R. Advertising: The magic system. Advert. Soc. Rev. 2000, 1. [CrossRef]

2. Brown, R.S., Jr. Advertising and the public interest: Legal protection of trade symbols. Yale LJ 1947, $57,1165$. [CrossRef]

3. Litman, J. Breakfast with Batman: The public interest in the advertising age. Yale Law J. 1999, 108, 1717-1735. [CrossRef]

4. Rossiter, J.R.; Percy, L. Advertising and Promotion Management; McGraw-Hill Book Company: New York, NY, USA, 1987.

5. Wells, W.; Burnett, J.; Moriarty, S.E.; Pearce, R.C.; Pearce, C. Advertising: Principles and Practice; Prentice Hall: Englewood Cliffs, NJ, USA, 1989; Volume 328.

6. Nelson, P. Advertising as information. J. Political Econ. 1974, 82, 729-754. [CrossRef]

7. Mehta, A. Advertising attitudes and advertising effectiveness. J. Advert. Res. 2000, 40, 67-72. [CrossRef]

8. Lavidge, R.J.; Steiner, G.A. A model for predictive measurements of advertising effectiveness. J. Mark. 1961, 25, 59-62. [CrossRef]

9. Bellman, S.; Robinson, J.A.; Wooley, B.; Varan, D. The effects of social TV on television advertising effectiveness. J. Mark. Commun. 2017, 23, 73-91. [CrossRef]

10. Yang, S.; Lin, S.; Carlson, J.R.; Ross, W.T., Jr. Brand engagement on social media: Will firms' social media efforts influence search engine advertising effectiveness? J. Mark. Manag. 2016, 32, 526-557. [CrossRef]

11. Fuller, D.A. Sustainable Marketing: Managerial-Ecological Issues; Sage Publications: New York, NY, USA, 1999. 
12. Goasduff, L. Gartner Says Worldwide Smartphone Sales Will Grow 3\% in 2020. Available online: https://www.gartner.com/en/newsroom/press-releases/2020-01-28-gartner-says-worldwide-smartphonesales-will-grow-3-- (accessed on 10 May 2020).

13. Kim, K.J.; Sundar, S.S. Mobile persuasion: Can screen size and presentation mode make a difference to trust? Hum. Commun. Res. 2016, 42, 45-70. [CrossRef]

14. Sung, J.; Cho, K. The influence of media type on attitude toward mobile advertisements over time. Cyberpsychol. Behav. Soc. Netw. 2012, 15, 31-36. [CrossRef] [PubMed]

15. McKay-Nesbitt, J.; Manchanda, R.V.; Smith, M.C.; Huhmann, B.A. Effects of age, need for cognition, and affective intensity on advertising effectiveness. J. Bus. Res. 2011, 64, 12-17. [CrossRef]

16. Sharma, M. Marketing myopia-a mousetrap that marketer should avoid. Int. Res. J. Manag. Sociol. Humanit. 2015, 6, 488-491.

17. De Pelsmacker, P.; Geuens, M.; Anckaert, P. Media context and advertising effectiveness: The role of context appreciation and context/ad similarity. J. Advert. 2002, 31, 49-61. [CrossRef]

18. Ducoffe, R.H.; Curlo, E. Advertising value and advertising processing. J. Mark. Commun. 2000, 6, $247-262$. [CrossRef]

19. Lannon, J.; Cooper, P. Humanistic advertising: A holistic cultural perspective. Int. J. Advert. 1983, 2, $195-213$. [CrossRef]

20. Holbrook, M.B.; Batra, R. Assessing the role of emotions as mediators of consumer responses to advertising. J. Consum. Res. 1987, 14, 404-420. [CrossRef]

21. Morris, J.D.; Woo, C.; Geason, J.A.; Kim, J. The power of affect: Predicting intention. J. Advert. Res. 2002, 42, 7-17. [CrossRef]

22. Gopinath, S.; Thomas, J.S.; Krishnamurthi, L. Investigating the relationship between the content of online word of mouth, advertising, and brand performance. Mark. Sci. 2014, 33, 241-258. [CrossRef]

23. Söderlund, M.; Rosengren, S. Receiving word-of-mouth from the service customer: An emotion-based effectiveness assessment. J. Retail. Consum. Serv. 2007, 14, 123-136. [CrossRef]

24. El Kadiri, S.; Grabot, B.; Thoben, K.-D.; Hribernik, K.; Emmanouilidis, C.; Von Cieminski, G.; Kiritsis, D. Current trends on ICT technologies for enterprise information systems. Comput. Ind. 2016, 79, 14-33. [CrossRef]

25. Buhalis, D.; O'Connor, P. Information communication technology revolutionizing tourism. Tour. Recreat. Res. 2005, 30, 7-16. [CrossRef]

26. Kim, K.J.; Sundar, S.S. Does screen size matter for smartphones? Utilitarian and hedonic effects of screen size on smartphone adoption. Cyberpsychol. Behav. Soc. Netw. 2014, 17, 466-473. [CrossRef] [PubMed]

27. Copeland, M.T. Principles of Merchandising; AW Shaw Company: Chicago, AW, USA, 1924.

28. Hall, M. Principles of Marketing. Econ. J. 1963, 73, 508-509. [CrossRef]

29. Albers-Miller, N.D.; Stafford, M.R. An international analysis of emotional and rational appeals in services vs goods advertising. J. Consum. Mark. 1999, 16, 42-57. [CrossRef]

30. Kotler, P.; Armstrong, G. Principles of Marketing; Pearson Education: London, UK, 2010.

31. Chiu, C.-M.; Hsu, M.-H.; Lai, H.; Chang, C.-M. Re-examining the influence of trust on online repeat purchase intention: The moderating role of habit and its antecedents. Decis. Support Syst. 2012, 53, 835-845. [CrossRef]

32. Harris, L.C.; Goode, M.M. The four levels of loyalty and the pivotal role of trust: A study of online service dynamics. J. Retail. 2004, 80, 139-158. [CrossRef]

33. Bolton, R.N.; Drew, J.H. A multistage model of customers' assessments of service quality and value. J. Consum. Res. 1991, 17, 375-384. [CrossRef]

34. Overby, J.W.; Lee, E.-J. The effects of utilitarian and hedonic online shopping value on consumer preference and intentions. J. Bus. Res. 2006, 59, 1160-1166. [CrossRef]

35. Chaudhuri, A.; Holbrook, M.B. The chain of effects from brand trust and brand affect to brand performance: The role of brand loyalty. J. Mark. 2001, 65, 81-93. [CrossRef]

36. Lin, K.-Y.; Lu, H.-P. Predicting mobile social network acceptance based on mobile value and social influence. Internet Res. 2015, 25, 107-130. [CrossRef]

37. Chiu, C.M.; Wang, E.T.; Fang, Y.H.; Huang, H.Y. Understanding customers' repeat purchase intentions in B2C e-commerce: The roles of utilitarian value, hedonic value and perceived risk. Inf. Syst. J. 2014, 24, 85-114. [CrossRef]

38. Arnold, M.J.; Reynolds, K.E. Hedonic shopping motivations. J. Retail. 2003, 79, 77-95. [CrossRef] 
39. Adaval, R. Sometimes it just feels right: The differential weighting of affect-consistent and affect-inconsistent product information. J. Consum. Res. 2001, 28, 1-17. [CrossRef]

40. Geuens, M.; De Pelsmacker, P.; Faseur, T. Emotional advertising: Revisiting the role of product category. J. Bus. Res. 2011, 64, 418-426. [CrossRef]

41. Simonson, I. The effect of product assortment on buyer preferences. J. Retail. 1999, 75, 347-370. [CrossRef]

42. Yang, Z.; Cai, S.; Zhou, Z.; Zhou, N. Development and validation of an instrument to measure user perceived service quality of information presenting web portals. Inf. Manag. 2005, 42, 575-589. [CrossRef]

43. Mimouni-Chaabane, A.; Volle, P. Perceived benefits of loyalty programs: Scale development and implications for relational strategies. J. Bus. Res. 2010, 63, 32-37. [CrossRef]

44. Childers, T.L.; Carr, C.L.; Peck, J.; Carson, S. Hedonic and utilitarian motivations for online retail shopping behavior. J. Retail. 2001, 77, 511-535. [CrossRef]

45. Johar, J.S.; Sirgy, M.J. Value-expressive versus utilitarian advertising appeals: When and why to use which appeal. J. Advert. 1991, 20, 23-33. [CrossRef]

46. Sullivan, Y.W.; Kim, D.J. Assessing the effects of consumers' product evaluations and trust on repurchase intention in e-commerce environments. Int. J. Inf. Manag. 2018, 39, 199-219. [CrossRef]

47. Rousseau, D.M.; Sitkin, S.B.; Burt, R.S.; Camerer, C. Not so different after all: A cross-discipline view of trust. Acad. Manag. Rev. 1998, 23, 393-404. [CrossRef]

48. Soh, H.; Reid, L.N.; King, K.W. Measuring trust in advertising. J. Advert. 2009, 38, 83-104. [CrossRef]

49. Chai, J.C.Y.; Malhotra, N.K.; Alpert, F. A two-dimensional model of trust-value-loyalty in service relationships. J. Retail. Consum. Serv. 2015, 26, 23-31. [CrossRef]

50. Koh, Y.J.; Sundar, S.S. Heuristic versus systematic processing of specialist versus generalist sources in online media. Hum. Commun. Res. 2010, 36, 103-124. [CrossRef]

51. Tarn, J.L. The effects of service quality, perceived value and customer satisfaction on behavioral intentions. J. Hosp. Leis. Mark. 1999, 6, 31-43. [CrossRef]

52. Gao, L.; Waechter, K.A.; Bai, X. Understanding consumers' continuance intention towards mobile purchase: A theoretical framework and empirical study-A case of China. Comput. Hum. Behav. 2015, 53, 249-262. [CrossRef]

53. Sanchez-Franco, M.J. The moderating effects of involvement on the relationships between satisfaction, trust and commitment in e-banking. J. Interact. Mark. 2009, 23, 247-258. [CrossRef]

54. Thoms, P.; Dose, J.J.; Scott, K.S. Relationships between accountability, job satisfaction, and trust. Hum. Resour. Dev. Q. 2002, 13, 307-323. [CrossRef]

55. Kampen, J.K.; De Walle, S.V.; Bouckaert, G. Assessing the relation between satisfaction with public service delivery and trust in Government. The impact of the predisposition of citizens toward Government on evalutations of its performance. Public Perform. Manag. Rev. 2006, 29, 387-404.

56. Jin, B.; Park, J.Y.; Kim, J. Cross-cultural examination of the relationships among firm reputation, e-satisfaction, e-trust, and e-loyalty. Int. Mark. Rev. 2008, 25, 324-337. [CrossRef]

57. Horppu, M.; Kuivalainen, O.; Tarkiainen, A.; Ellonen, H.K. Online satisfaction, trust and loyalty, and the impact of the offline parent brand. J. Prod. Brand Manag. 2008, 17, 403-413. [CrossRef]

58. Şahin, A.; Turhan, L.; Zehir, A. Building behavioral intentions in automotive industry: Brand experience, satisfaction, trust, direct mail communication and attitudes toward advertising. Bus. Manag. Dyn. 2013, 3, 45.

59. Bulearca, M.; Tamarjan, D. Augmented reality: A sustainable marketing tool. Glob. Bus. Manag. Res. Int. J. 2010, 2, 237-252.

60. Sun, Y.; Ko, E. Influence of sustainable marketing activities on customer equity. J. Glob. Sch. Mark. Sci. 2016, 26, 270-283. [CrossRef]

61. Kumar, V.; Mirchandani, R. Increasing the ROI of social media marketing. MIT Sloan Manag. Rev. 2012, 54, 55. [CrossRef]

62. Abubakar, A.M.; Ilkan, M. Impact of online WOM on destination trust and intention to travel: A medical tourism perspective. J. Destin. Mark. Manag. 2016, 5, 192-201. [CrossRef]

63. Choi, B.; Choi, B.-J. The effects of perceived service recovery justice on customer affection, loyalty, and word-of-mouth. Eur. J. Mark. 2014, 48, 108-131. [CrossRef]

64. WeintraubAustin, E.; Miller, A.C.-R.; Silva, J.; Guerra, P.; Geisler, N.; Gamboa, L.; Phakakayai, O.; Kuechle, B. The effects of increased cognitive involvement on college students' interpretations of magazine advertisements for alcohol. Commun. Res. 2002, 29, 155-179. [CrossRef] 
65. Okazaki, S.; Katsukura, A.; Nishiyama, M. How mobile advertising works: The role of trust in improving attitudes and recall. J. Advert. Res. 2007, 47, 165-178. [CrossRef]

66. Fang, Y.H.; Chiu, C.M.; Wang, E.T. Understanding customers' satisfaction and repurchase intentions. Internet Res. 2011, 21, 479-503. [CrossRef]

67. Hsu, M.-H.; Chang, C.-M.; Chu, K.-K.; Lee, Y.-J. Determinants of repurchase intention in online group-buying: The perspectives of DeLone \& McLean IS success model and trust. Comput. Hum. Behav. 2014, 36, 234-245.

68. Hong, S.Y.; Yang, S.-U. Effects of reputation, relational satisfaction, and customer-company identification on positive word-of-mouth intentions. J. Public Relat. Res. 2009, 21, 381-403. [CrossRef]

69. Wirtz, J.; Chew, P. The effects of incentives, deal proneness, satisfaction and tie strength on word-of-mouth behaviour. Int. J. Serv. Ind. Manag. 2002, 13, 141-162. [CrossRef]

70. Jiewanto, A.; Laurens, C.; Nelloh, L. Influence of service quality, university image, and student satisfaction toward WOM intention: A case study on Universitas Pelita Harapan Surabaya. Procedia Soc. Behav. Sci. 2012, 40, 16-23. [CrossRef]

71. Maxham, J.G., III. Service recovery's influence on consumer satisfaction, positive word-of-mouth, and purchase intentions. J. Bus. Res. 2001, 54, 11-24. [CrossRef]

72. Ranaweera, C.; Prabhu, J. On the relative importance of customer satisfaction and trust as determinants of customer retention and positive word of mouth. J. Target. Meas. Anal. Mark. 2003, 12, 82-90. [CrossRef]

73. Agag, G.; El-Masry, A.A. Understanding consumer intention to participate in online travel community and effects on consumer intention to purchase travel online and WOM: An integration of innovation diffusion theory and TAM with trust. Comput. Hum. Behav. 2016, 60, 97-111. [CrossRef]

74. Wang, E.S.-T.; Chen, L.S.-L. The influence of perceived justice of service recovery on affective and cognitive trust. Int. J. Serv. Stand. 2011, 7, 278-290. [CrossRef]

75. $\mathrm{Xu}, \mathrm{Q}$. Should I trust him? The effects of reviewer profile characteristics on eWOM credibility. Comput. Hum. Behav. 2014, 33, 136-144. [CrossRef]

76. Alfina, I.; Ero, J.; Hidayanto, A.N.; Shihab, M.R. The impact of cognitive trust and e-wom on purchase intention in C2C e-commerce site. J. Comput. Sci. 2014, 10, 2518. [CrossRef]

77. Becker, J.-M.; Rai, A.; Ringle, C.M.; Völckner, F. Discovering unobserved heterogeneity in structural equation models to avert validity threats. Mis Q. 2013, 37, 665-694. [CrossRef]

78. Rust, R.T.; Verhoef, P.C. Optimizing the marketing interventions mix in intermediate-term CRM. Mark. Sci. 2005, 24, 477-489. [CrossRef]

79. Gormley, T.A.; Matsa, D.A. Common errors: How to (and not to) control for unobserved heterogeneity. Rev. Financ. Stud. 2014, 27, 617-661. [CrossRef]

80. Mannering, F.L.; Shankar, V.; Bhat, C.R. Unobserved heterogeneity and the statistical analysis of highway accident data. Anal. Methods Accid. Res. 2016, 11, 1-16. [CrossRef]

81. Krasnokutskaya, E. Identification and estimation of auction models with unobserved heterogeneity. Rev. Econ. Stud. 2011, 78, 293-327. [CrossRef]

82. Sarstedt, M.; Ringle, C.M.; Hair, J.F. Treating unobserved heterogeneity in PLS-SEM: A multi-method approach. In Partial Least Squares Path Modeling; Springer: Berlin/Heidelberg, Germany, 2017; pp. 197-217.

83. Fuentes-Blasco, M.; Moliner-Velázquez, B.; Gil-Saura, I. Analyzing heterogeneity on the value, satisfaction, word-of-mouth relationship in retailing. Manag. Decis. 2017, 55, 1558-1577. [CrossRef]

84. Lu, S.; Wang, X.; Bendle, N. Does Piracy Create Online Word of Mouth? An Empirical Analysis in the Movie Industry. Manag. Sci. 2019, 66, 1783-2290. [CrossRef]

85. Yang, S.; Hu, M.; Winer, R.S.; Assael, H.; Chen, X. An empirical study of word-of-mouth generation and consumption. Mark. Sci. 2012, 31, 952-963. [CrossRef]

86. Duan, W.; Gu, B.; Whinston, A.B. The dynamics of online word-of-mouth and product sales-An empirical investigation of the movie industry. J. Retail. 2008, 84, 233-242. [CrossRef]

87. Rahim, A.; Safin, S.Z.; Kheng, L.K.; Abas, N.; Ali, S.M. Factors influencing purchasing intention of smartphone among university students. Procedia Econ. Financ. 2016, 37, 245-253. [CrossRef]

88. Deloitte. Global Mobile Consumer Survey: US Edition. 2017. Available online: https://www2.deloitte.com/content/ dam/Deloitte/us/Documents/technology-media-telecommunications/us-tmt-2017-global-mobile-consumersurvey-executive-summary.pdf (accessed on 31 May 2020). 
89. Silver, L. Smartphone Ownership Is Growing Rapidly Around the World, but Not Always Equally. Available online: https:/www.pewresearch.org/global/2019/02/05/in-emerging-economies-smartphoneadoption-has-grown-more-quickly-among-younger-generations/ (accessed on 31 May 2020).

90. Rosselli, F.; Skelly, J.J.; Mackie, D.M. Processing rational and emotional messages: The cognitive and affective mediation of persuasion. J. Exp. Soc. Psychol. 1995, 31, 163-190. [CrossRef]

91. Ringle, C.M.; Wende, S.; Becker, J.-M. SmartPLS 3. Bönningstedt: SmartPLS. Retrieved July 2015, 15, 2016.

92. Esposito Vinzi, V.; Trinchera, L.; Squillacciotti, S.; Tenenhaus, M. REBUS-PLS: A response-based procedure for detecting unit segments in PLS path modelling. Appl. Stoch. Models Bus. Ind. 2008, 24, 439-458. [CrossRef]

93. Hair, J.F., Jr.; Sarstedt, M.; Ringle, C.M.; Gudergan, S.P. Advanced Issues in Partial Least Squares Structural Equation Modeling; Sage Publications: New York, NY, USA, 2017.

94. Podsakoff, P.M.; Organ, D.W. Selfreports in Organizational Research: Problems and Prospects. J. Manag. 1986, 12, 531-544.

95. Podsakoff, P.M.; MacKenzie, S.B.; Lee, J.-Y.; Podsakoff, N.P. Common method biases in behavioral research: A critical review of the literature and recommended remedies. J. Appl. Psychol. 2003, 88, 879. [CrossRef] [PubMed]

96. Podsakoff, P.M.; MacKenzie, S.B.; Podsakoff, N.P. Sources of method bias in social science research and recommendations on how to control it. Annu. Rev. Psychol. 2012, 63, 539-569. [CrossRef]

97. Fornell, C.R.; Lacker, D.F. Two structural equation models with unobservable variables and measurement error. J. Mark. Res. 1981, 18, 39-50. [CrossRef]

98. Kline, E.; Wilson, C.; Ereshefsky, S.; Tsuji, T.; Schiffman, J.; Pitts, S.; Reeves, G. Convergent and discriminant validity of attenuated psychosis screening tools. Schizophr. Res. 2012, 134, 49-53. [CrossRef]

99. Henseler, J.; Ringle, C.M.; Sarstedt, M. A new criterion for assessing discriminant validity in variance-based structural equation modeling. J. Acad. Mark. Sci. 2015, 43, 115-135. [CrossRef]

100. Hair, J.F., Jr.; Hult, G.T.M.; Ringle, C.; Sarstedt, M. A Primer on Partial Least Squares Structural Equation Modeling (PLS-SEM); Sage Publications: New York, NY, USA, 2016.

101. Liebana-Cabanillas, F.; Alonso-Dos-Santos, M. Factors that determine the adoption of Facebook commerce: The moderating effect of age. J. Eng. Technol. Manag. 2017, 44, 1-18. [CrossRef] 